\title{
Position of the Red Honey bee, Apis koschevnikovi (Buttel-Reepen 1906), within the Genus Apis
}

\author{
F. Ruttner ${ }^{1}$, D. Kauhausen 2 and N. Koeniger ${ }^{1}$ \\ 1 Universität Frankfurt, Institut für Bienenkunde (Polytechn. Gesellschaft), D-6370 Oberursel, FRG \\ 2 Bayerische Landesanstalt für Bienenzucht, D-8520 Erlangen, FRG
}

(received 19 December 1989, accepted 29 March 1989)

\begin{abstract}
Summary - The "Red Bee" of Borneo, described in 1988 by Koeniger et al. and Tingek et al. as a separate species, was first named by $H$. v. Buttel-Reepen in 1906. The correct name, therefore, is Apis koschevnikovi Buttel-Reepen 1906 and not Apis vechti Maa 1953. By multivariate analysis (PCA and DA) Apis koschevnikovi can clearly be separated from the 2 other cavity-nesting Apis species. Although $A$. koschevnikovi is very similar to $A$. cerana phenotypically, it is much larger than bees of this species from a similar geographic latitude, corresponding in size to equatorial populations of $A$. mellifera from Africa.
\end{abstract}

Apis - taxonomy - Apis koschevnikovi- morphometrics - Borneo

\section{THE CORRECT SCIENTIFIC NAME}

In the spring of 1988, Koeniger et al. and Tingek et al. published data on the taxonomic status of a special honey bee from S.E. Asia as a true species which they determined as Apis vechti (Maa, 1953). But this was not the first description of this honey bee, very conspicuous by its reddish legs and hair, and by its size. ButtelReepen (1906) found several specimens of this kind in the Museum of Natural History in Berlin which were labelled as "Cameroon", and one as "N. Borneo". He dismissed the possibility as unlikely, and named this cerana-type honey bee "Apis mellifica indica-koschevnikovi" [in ButtelReepen's taxonomic system $A$. indica (= A. cerana) was taken as a subspecies of A. mellifera. The prefix "indica" was used by Buttel-Reepen to show the relationship of his new form, but elsewhere in the same work he referred to it as koschevnikovi. There is no doubt but that koschevnikovi by itself is the name for this bee]. To him, the specimens at the Berlin Museum were evidence that $A$. cerana also occurs on the African continent.

About 50 years later (1953) Maa described a number of specimens of the "Red Bee", all collected in Borneo, in his taxonomic revision of the genus Apis. Maa considered the "Red Bee" to be a separate species and gave it a new name, Apis vechti (after the entomologist J. Van der Vecht then of the Bogor Museum, now Putten, The Netherlands). He even noticed a certain geographic variability sufficient to establish 2 subspecies ("vechti" and "linda"). Maa did not reevaluate the specimens of the Berlin Museum and proposed retaining the name 
"A. koschevnikovi" for the supposedly African "Red Bee".

The present situation is as follows :

1) "Apis vechti" is a true species: it differs from $A$. cerana in the endophallus (Tingek et al., 1988) and time of drone flight (= reproductive isolation; Koeniger et al., 1988). It is sympatric with $A$. cerana indica.

2) There is no evidence yet that a ceranatype honey bee exists on the African continent. Mislabelling of the specimens at the Berlin Museum is the most probable explanation for the present confusing situation. Consequently, 2 names are probably used for the same bee of the same area. After consulting $\mathrm{Dr}$ Charles Michener in this matter, we asked Dr Frank Koch, Museum für Naturkunde (Humboldt Universität, Berlin) to re-examine the specimens described by Buttel-Reepen in 1906 (which have miraculously survived the last 83 years) to confirm their cerana-type characters. The following criteria were used which discriminate best between $A$. cerana and $A$. mellifera :

i) prolongation of radial vein of hind wing ("indica vein") - present;

ii) tomentum on last tergite-present;

iii) number of hamuli on hind wing -17 to 19.

Thus there is no doubt that all of ButtelReepen's specimens are cerana-type and that they were not collected in Cameroon but most likely in Borneo. According to the rules of priority, the name " $A$. vechti" is redundant and the correct scientific name of the Red Honey bee has to be Apis koschevnikovi (Buttel-Reepen, 1906).

Here it should be noted that no type similar to the "Red Bee" is among the various honeybees collected by Wallace in North Borneo and described by Smith (1858; 1865); he lists A. dorsata and a variety of this species, $A$. testacea, $A$. indica with the variety perrottetii and $A$. andreni- formis, all clearly different from A. koschevnikovi. These findings raise the question of the position of this species between the other 4 known recent Apis species.

\section{MATERIAL AND METHODS}

For the morphometric analysis of the "Red Bee", two sets of data were used.

\section{Phenetic analysis including fossil hon- eybees}

Characters of 12 individuals of $A$. koschevnikovi and 12 of $A$. cerana indica, both from the region of Tenom, Sabah, N. Borneo, were analysed together with data on individual honey bees as used in an earlier analysis (Ruttner et al., 1986). The origin of these bees was the following:

1) A. armbrusteri - Schwäbische Alb, Upper Miocene, 10 specimens

2) A. dorsata - Pakistan, 10 specimens

3) A. florea - Pakistan, 10 specimens

4) A. cerana cerana - Afghanistan, 10 specimens

5) A. mellifera - Iran, 10 specimens.

The characters used were 16 wing venation angles; no characters of size were included. The multivariate statistical methods were factor and discriminant analyses (PCA, DA). Both methods gave basically identical results. Finally, ellipses of confidence were calculated (Cornuet, 1982).

\section{Taxonomic-morphometric analysis}

In these analyses all 34 characters were used as in the standard method of honey bee morphometry (Ruttner et al., 1978; Ruttner, 1988); not individual bees but the means of samples of $15-20$ bees were taken as units. Five samples of A. koschevnikovi from N. Borneo and 1 sam- 
ple from Sumatra were analysed together with samples of $A$. cerana of various origins and of tropical populations (Arabia, E. Africa) of A. mellifera.

Voucher specimens of $A$. koschevnikovi have been placed for permanent preservation in the Honeybee Taxonomy Collection of the Institut für Bienenkunde Oberursel, University of Frankfurt.

\section{RESULTS}

\section{Phenetic analysis}

As was to be expected, the positions of the clusters are identical with those of an earlier investigation of fossil and known recent species : the fossil $A$. armbrusteri and $A$. dorsata are represented as a common cluster, with only slight differentiation of the 2 species (Figs. 1 and 2). A. koschevnikovi appears together with the 2 other cavity-nesting species as 3 separate clusters without overlapping, $A$. cerana in the centre and $A$. mellifera at the periphery. The cluster of $A$. koschevnikovi is found in direct contact with that of $A$. cerana, but distant from the mellifera cluster. The cerana samples from Borneo are at the centre of the general cerana cluster (Fig. 2B). In the graph showing the ellipses of confidence (95\%, Fig. 2), the $\mathrm{K}$ cluster heavily overlaps the $\mathrm{C}$ cluster but not the $\mathrm{M}$ cluster.

\section{Taxonomic analysis}

The samples of $A$. cerana are arranged in 2 separate groups (Fig. 3). While the popu-

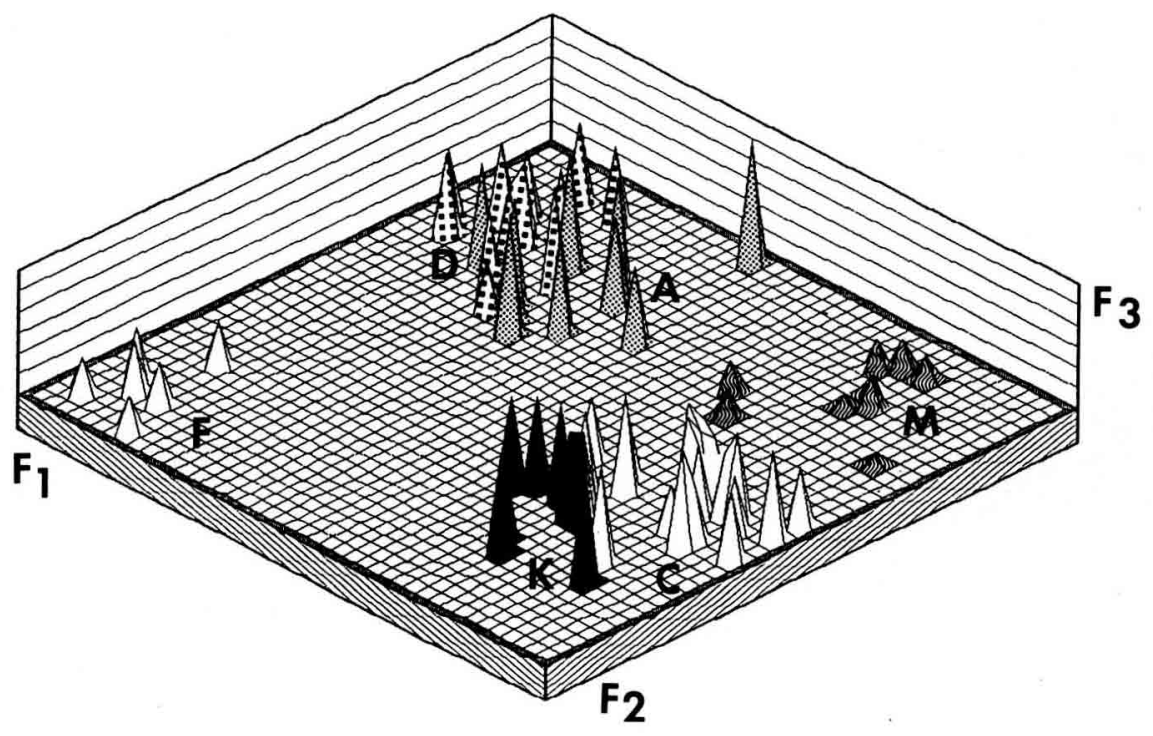

Fig. 1. Discriminant analysis of specimens of all known Apis species including fossils from the Miocene. Characters: 16 wing venation angles. 3D graph with the three first factors : A A. armbrusteri; C A. cerana; D A. dorsata; F A. florea; K A. koschevnikovi; M A. mellifera. 


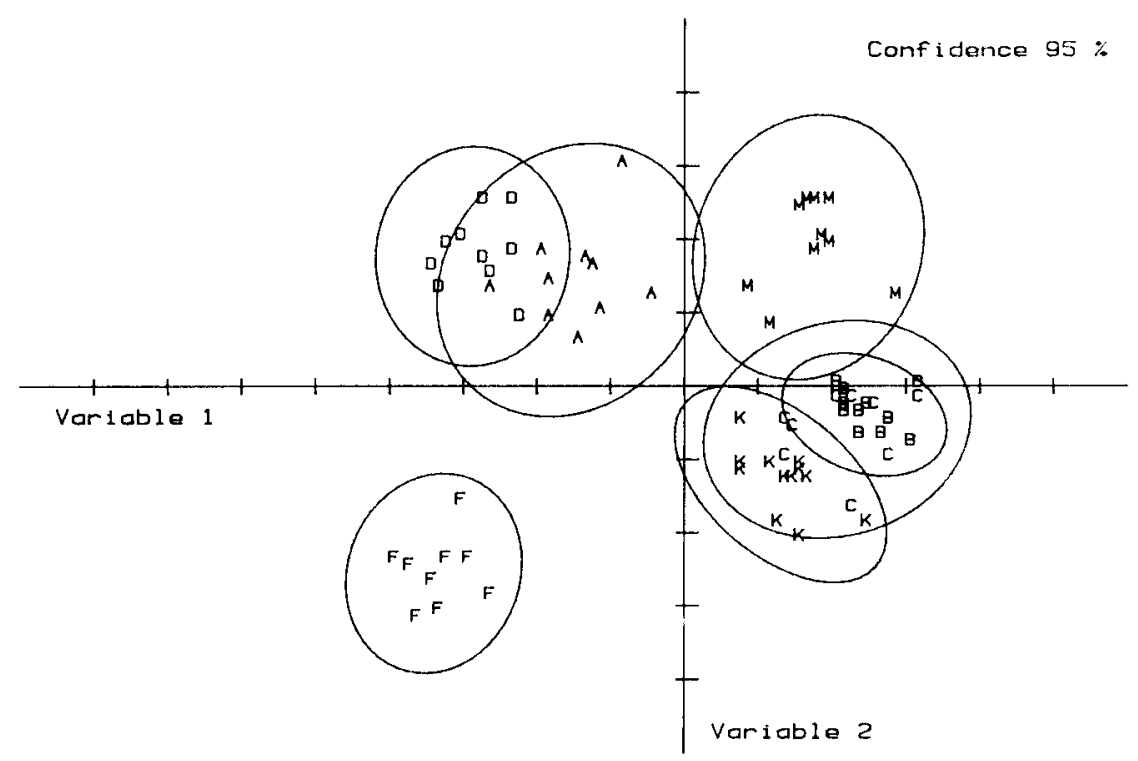

Fig. 2. Discriminant analysis as in Fig. 1 with ellipses of confidence (95\%). Factors 1 and 2. B A. cerana indica from Borneo; other letters as in Fig. 1.

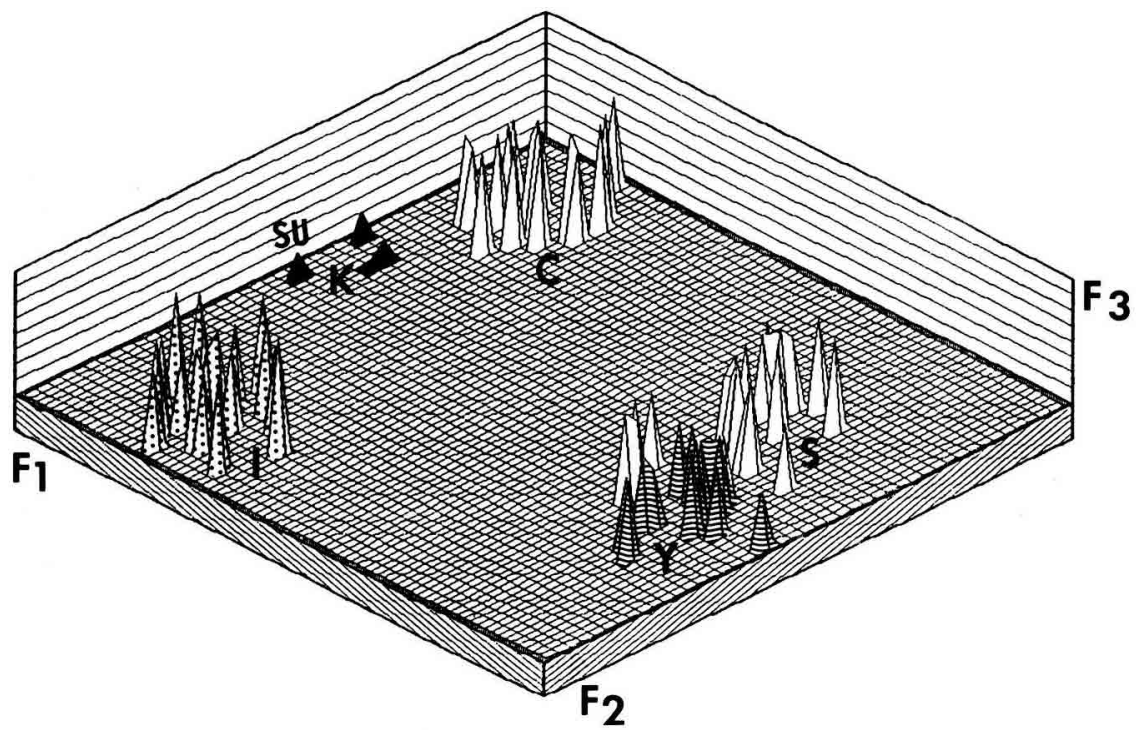

Fig. 3. Discriminant analysis of samples of: C A. cerana cerana; I A.c. indica; K A. koschevnikovi; Y A. mellifera yemenitica; S A. m. scutellata; SU sample of $A$. koschevnikovi from Sumatra. 
lations with small bees of the subspecies A. cerana indica from S. India, Sri Lanka, Thailand, Indonesia, etc. appear to the left, the samples of the large $A$. cerana cerana from Afghanistan, Pakistan, N. India, China, and those of $A$. cerana japonica are to the right. The clusters of the tropical mellifera populations are at great distance in the far right corner.

The cluster of the $5 \mathrm{~A}$. koschevnikovi samples (15 bees each) from Borneo is found between these 2 groups (Fig. 3), close to that of $A$. cerana cerana, the closest samples being the populations from S.W. China (Yunnan, Fig. 3). When ellipses of confidence are calculated, $A$. koschevnikovi overlaps with $A$. c. japonica in the graph of factor $1 /$ factor 2 , but it is well separated in the graphs of factors $1 / 3$ (Fig. 4). In this analysis (1/2) the distance of the A. koschevnikovi centroid to the centroid of A. c. cerana is less than the distance be- tween the centroids of A.C. cerana and $A$. c. indica.

If the group $A$. koschevnikovi-A. cerana is analysed by itself, that is including exclusively samples of these 2 species, the cerana subspecies appear in one compact, only slightly subdivided cluster, while the koschevnikovi samples are found in a remote, compact aggregation (Fig. 5).

One sample (No. 991; 20 bees) from Sumatra, collected in 1978 by one of the authors (Koeniger) in Muaro near Solok, is separated from the $A$. $c$. indica cluster by a great distance, but very close to the $A$. koschevnikovi samples (Fig. 3). These honey bees show the same typical rufous color of legs and abdomen as A. koschevnikovi; their size is somewhat smaller than that of $A$. koschevnikovi from Borneo, but they are much larger than indica bees from Sumatra, and the cubital index and the index of st 6 show the typical extreme values

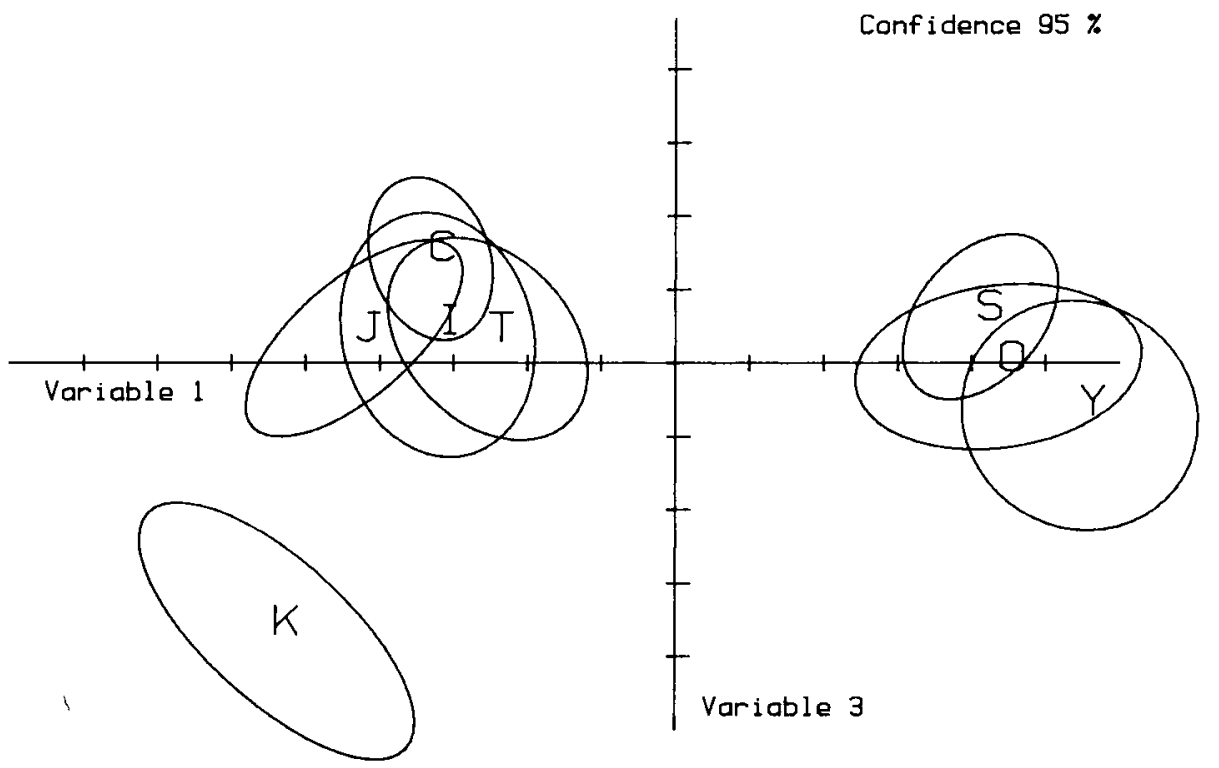

Fig. 4. Discriminant analysis as in Fig. 3 (factors 1 and 3 ) with ellipses of confidence $95 \%$. C A. cerana from China; I ,T $A$. cerana indica from Indonesia and Thailand; $J A$. cerana japonica; $O, Y$. mellifera yemenitica from Somalia and Yemen; S A. m. scutellata; K A. koschevnikovi. 


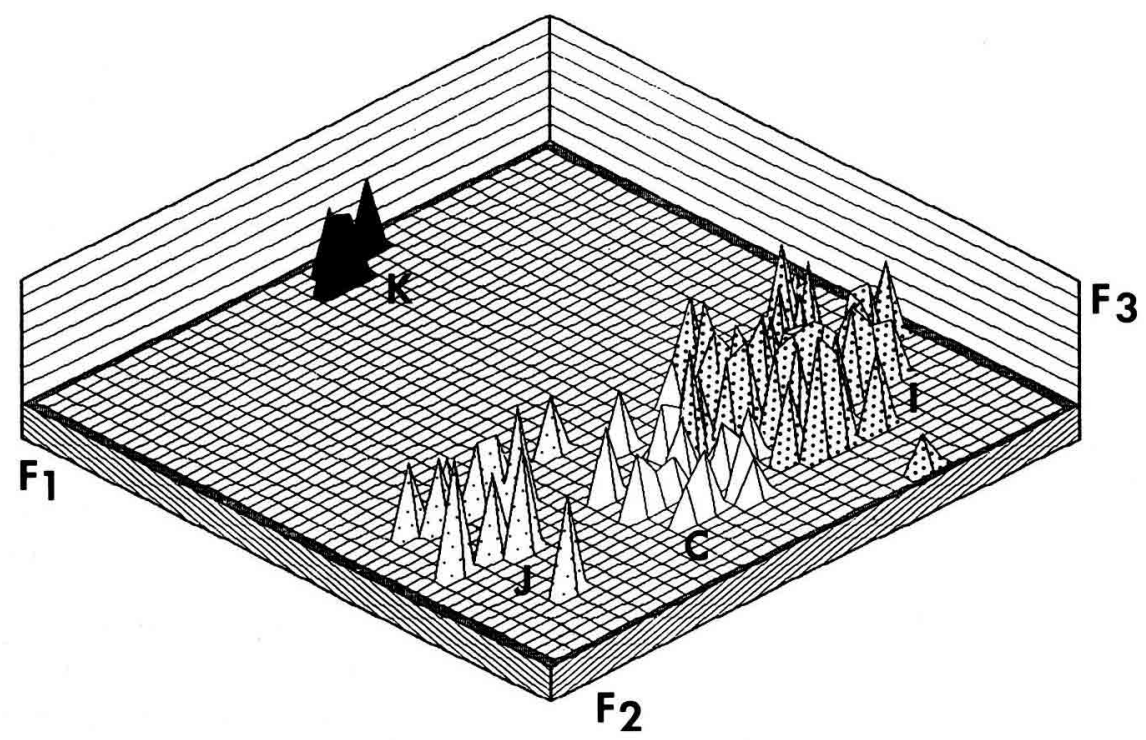

Fig. 5. Discriminant analysis of samples of A. cerana (right) and K A. koschevnikovi; C A. c. cerana; I A. c. indica; J A. c. japonica.

of $A$. koschevnikovi. The following data are arranged in the sequence $A$. koschevnikovi Borneo - sample 991 (Sumatra) - A. c. indica Sumatra (6 samples; in $\mathrm{mm}$ ) : length of fore wing, 8.541-8.264-7.769; length of hind leg, 7.612-7.558-6.839; tergites $3+4,3.987-3.886-3.535$; index of sternite 6, 89.56-90.24-86.50; cubital index, 7.59-7.86-4.34. There is no doubt, therefore, that the sample from Sumatra belongs to the same taxonomic unit as the samples of $A$. koschevnikovi from Borneo.

\section{DISCUSSION}

Apis koschevnikovi can be separated from all the other Apis species by quantitative characters (Figs. $1,3,5$ ), but the level of confidence is low for discrimination from $A$. cerana if very different, remote species are included such as the Miocenic $A$. armbrusteri, a fossil honeybee which lived 12 million years ago (Fig. 2). But even in this case, almost no overlapping occurs with the ellipse of confidence ( $95 \%$ ) of sympatric A. c. indica from Borneo. A good discrimination is obtained, however, if only the closely related cavity-nesting species $A$. cerana and $A$. mellifera are included in the analysis (Figs. 3, 4 and 5).

in $A$. koschevnikovi, only a few of the characters generally used in honey bee morphometrics are outside or at an extreme end of the known range of $A$. cerana (see Ruttner, 1988). A. koschevnikovi is very long-tongued $(5.870 \mathrm{~mm})$, slender (st6-1 89.6), with narrow tomenta (tom-1 0.389 ) and high $\mathrm{Cl}$ (7.59). All the other characters, especially those of size, are well within the range of cerana populations of the temperate zone. The most conspicu- 
ous character by which "this species can very easily be distinguished from any other honey bee species is the uniform rufous pattern" (Maa, 1953).

Evidently, the overlapping of the A. koschevnikovi and the cerana clusters is mainly due to characters of size. Axis 3 of a DA, which contains no characters of size (length of vertical bars in Fig. 3), clearly increases the distance $A$. koschevnikovi A. cerana. Size in honey bees, however, is highly correlated to geographic latitude within the range of a species. Therefore it seems appropriate to introduce an additional parameter into the taxonomic analysis : geographic latitude. All the Apis species investigated so far (mellifera, cerana, florea; Ruttner, 1988) clearly follow Bergmann's rule. A correlation coefficient of $0.7-0.9$ was found for most characters of size and geographic latitude in $A$. mellifera (Ruttner, 1985). Therefore, a taxonomic distortion will result if equatorial populations are compared with those of higher geographic latitudes. The samples of the "Red Bee" were collected in N. Borneo (Sabah) at $2^{\circ} \mathrm{N}$ latitude. The sympatric $A$. cerana subsp. indica is much smaller (Rinderer et al., 1989), very much like the populations of Java, Sumatra, Sri Lanka and S. India. A. koschevnikovi compares in size with the cerana bees of the mountains of Yunnan $\left(25^{\circ}\right.$ ) and from Honan (near Tokyo, $36^{\circ}$, Table 1). A similar gradation is found in A. mellifera (Ruttner, 1986); on this scale, $A$. koschevnikovi compares in size with the bees from Cameroon ( $\left.4{ }^{\circ} \mathrm{S}\right)$ and Lamu (coast of Kenya, $2^{\circ} \mathrm{N}$ ). Assuming the same scale of gradation, an $\boldsymbol{A}$. koschevnikovi of the temperate zone would be of the size of $A$. mellifera (Table 1). This, however, is a completely different scale of size variation than in $A$. cerana, thus furnishing another factor to distinguish this species.

The morphometric characters aside, various others can be listed to show the close relation of $A$. koschevnikovi to $A$. ce-

Table I. Measurements of size: means of samples from various geographic latitutes (in mm).

\begin{tabular}{lrrrrr}
\multicolumn{1}{c}{$\begin{array}{c}\text { Origin } \\
\text { sample No. }\end{array}$} & $\begin{array}{c}\text { Geogr. } \\
\text { latitude }\end{array}$ & $\begin{array}{c}\text { T3+4 } \\
\text { length }\end{array}$ & $\begin{array}{c}\text { Stern3 } \\
\text { length }\end{array}$ & $\begin{array}{c}\text { Fwing } \\
\text { length }\end{array}$ & 3d leg \\
\hline a) A. mellifera & & & & & \\
Cameroun no. 854 & $4^{\circ}$ & 3.972 & 2.420 & 8.267 & 7.386 \\
Lamu (Kenya) no. 871 & $2^{\circ}$ & 3.950 & 2.539 & 8.429 & 7.430 \\
Avignon, France, no. 402 & $40^{\circ}$ & 4.504 & 2.764 & 9.210 & 8.129 \\
Shannon, Eire, no. 1454 & $53^{\circ}$ & 4.843 & 2.959 & 9.745 & 8.555 \\
& & & & & \\
b) A. cerana & $2^{\circ}$ & 3.379 & 2.104 & 7.504 & 6.459 \\
Borneo, no. 1486 & $25^{\circ}$ & 3.958 & 2.477 & 8.840 & 7.512 \\
Yunnan, no. 1371 & $36^{\circ}$ & 4.149 & 2.629 & 8.889 & 7.738 \\
Tokyo, Japan, no. 945 & & & & & \\
C) A. koschevnikovi & $2^{\circ}$ & 3.987 & 2.574 & 8.541 & 7.612 \\
Borneo (1) & & & & & \\
\hline
\end{tabular}

(1) : Mean of 5 samples. 
rana: tomentum on the last tergite; "indica vein" of the hind wing; shape of endophallus; and pore in the capping of drone cells. It cannot be overlooked, however, that there are characters which indicate a certain affinity to $A$. dorsata which is frequently considered as an ancestral type in relation to the cavity-nesting species: size of a honeybee in S. Asia; slender abdomen; high cubital index; smokey tinge of wings. Methods of molecular biology might provide further evidence of the phylogenetic relationship among the honey bees of $S$. Asia.

As noted above, A. koschevnikovi is not restricted to Borneo. A sample in the Oberursel data bank, collected 10 years ago near Solok in Sumatra and listed as an isolated, "aberrant" type, clearly belongs to this species. The true area of distribution of the species has yet to be investigated. A certain conclusion can be made about the age of the species. The Indonesian Islands were separated from the continent only during the sea level rise in the post-pleistocenic period. The island population of $A$. C. indica, therefore, has not even reached the status of a subspecies (Ruttner, 1988). The separation of the two species $A$. koschevnikovi and $A$. cerana certainly occurred in a much earlier period.

\section{ACKNOWLEDGMENTS}

We wish to thank Dr Frank Koch, Museum für Naturkunde der Humboldt-Universität Berlin, Dr Christopher O'Toole, The University Museum Oxford, and Professor Charles Michener, Snow Entomological Museum, Lawrence, Kansas, USA; for their kind and helpful cooperation in the process of clarifying the confusing nomenclature of the "Red Bee". Agnes Mohr, Oberursel, was as reliable as ever in taking all the measurements and adapting the figures. $E$.
Hüttinger and Dr. R. Keller assisted in computing the graphs.

Résumé - La position de l'abeille rouge, Apis koschevnikovi (ButtelReepen 1906) au sein du genre Apis. Depuis qu'il existe une science de l'abeille, des centaines d'espèces ont été décrites mais seules 4 espèces ont acquis une valeur durable. Aussi cela fit-il du bruit lorsqu'en 1988 Koeniger et al. et Tingek et al. montrèrent dans deux courtes notes qu'il existait à Bornéo une autre espèce nidifiant dans les cavités, remarquable par sa couleur rouge cuivre et identifiée comme espèce propre en raison de la forme de l'endophallus et d'un décalage dans la période de vol des mâles empêchant le croisement : Apis vechti (Maa, 1953). Mais, entretemps des recherches ont montré que la même abeille avait vraisemblablement déjà été décrite en 1906 par l'entomologiste berlinois $\mathrm{H}$. von Buttel-Reepen sous le nom d'A. indica koschevnikovi, d'après des exemplaires de musée dont l'origine était marquée parfois "Cameroun" parfois "Bornéo». Le préfixe "indica» (aujourd'hui synonyme de cerana) devait indiquer la ressemblance avec l'abeille orientale. Puisqu'aujourd'hui on sait précisément qu'A. cerana est absente d'Afrique, il faut admettre une erreur dans l'étiquetage, dans le cas où les abeilles présentent réellement des caractéristiques cerana. Grâce à l'amicale collaboration du Dr Frank Koch, du Museum d'Histoire Naturelle de l'Université Humboldt à Berlin, on a pu apporter la preuve sur des exemplaires conservés intégralement, qu'ils ne provenaient assurément pas d'Afrique maid du sud-est asiatique. Selon la règle de priorité leur nom d'origine $A$. koschevnikovi doit être conservé.

Pour l'analyse morphologique de la nouvelle abeille, on disposait de 5 échantillons 
de 20 abeilles chacun récoltés dans le Nord de Bornéo (Sabah). Un autre échantillon de Sumatra, déjà présent dans la collection d'Oberursel, a pu être déterminé plus tard comme "Abeille rouge". Les échantillons de comparaison provenaient de la même collection.

Pour déterminer la place d'A. koschevnikovi au sein du genre Apis, on a d'abord fait une analyse discriminante (limitée aux caractéristiques de l'aile) sur toutes les espèces connues d'Apis, y compris $A$. armbrusteri vieille de 12 millions d'années (Fig. 1). Les exemplaires de l'Abeille rouge se trouvent dans un groupe individualisé, étroitement appuyé contre $A$. cerana mais très éloigné d' $A$. mellifica. Si l'on calcule les ellipses de confiance à $95 \%$, celles d' $A$. koschevnikovi et d' $A$. cerana se recouvrent fortement (Fig. 2).

Si l'on analyse seules les 3 espèces d'Apis qui nidifient dans des cavités, les échantillons d'A. koschevnikovi sont situés entre les formes grandes ( $A$. c. cerana) et les formes petites ( $A$. C. indica) d'A. cerana, bien loin des races tropicales d'A. mellifica (Fig. 3). Les ellipses de confiance à $95 \%$ ne montrent aucun recouvrement (Fig. 4). Si finalement on teste seule l'Abeille rouge contre $A$. cerana avec toutes ses races, une délimitation très nette apparaît (Fig. 5).

A. koschevnikovi est nettement plus grande que la population locale d'A. $c$. cerana; sa taille correspond à peu près à celle des races d' $A$. mellifica de la même latitude (Tableau I). Puisque chez toutes les espèces d'abeilles la taille augmente du sud au nord, on peut admettre qu' $A$. koschevnikovi montrerait la même ampleur de variation de la taille qu'A. mellifica si elle avait réussi à pénétrer dans la zone tempérée.
Zusammenfassung - Die Stellung der
Roten Biene, Apis koschevnikovi (But-
tel-Reepen 1906) in der Gattung Apis. Seit es eine Wissenschaft von der Honigbiene gibt, wurden hunderte von Bienenarten beschrieben, aber nur vier Arten hatten bisher dauernde Gültigkeit. Darum erregte es umso größeres Aufsehen, als 1988 Koeniger u.Mitarb. und Tingek u. Mitarb. in zwei kurzen Arbeiten zeigen konnten, daß es in Borneo eine weitere, höhlenbrütende Art gibt, auffällig durch ihre kupferrote Körperfarbe und als eigene Spezies ausgewiesen durch eine andere Form des männlichen Begattungsschlauches sowie durch eine Verschiebung der Drohnenflugzeit als Kreuzungshemnis: Apis vechti (Maa, 1953). Inzwischen angestellte Nachforschungen haben aber ergeben, daß vermutlich dieselbe Bienenart schon 1906 von dem Berliner Entomologen H. v. Buttel-Reepen an Hand von Museumsexemplaren, deren Herkunft z. T. als "Kamerun", z.T. als "Borneo" angegeben war, unter dem Namen $A$. indicakoschevnikovi beschrieben worden war. Der Zuname "indica" (heute gleichbedeutend mit $A$. cerana) sollte auf die Ähnlichkeit mit der Östlichen Honigbiene hinweisen. Da man heute genau weiß, daß in Afrika $A$. cerana nicht vorkommt, ist ein Irrtum in der Etikettierung anzunehmen, falls diese Bienen tatsächlich ceranaMerkmale aufweisen. Dank der freundlichen Mitarbeit von Dr. Frank Koch, Naturkundliches Museum der HumboldtUniversität Berlin, konnte dieser Nachweis an den vollständig erhaltenen Exemplaren geführt werden, die somit sicherlich nicht aus Afrika, sondern aus SO Asien stammen und nach der Prioritätsregel ihren ursprünglichen Namen $A$. koschevnikovi behalten müssen. 
Zur morphometrischen Analyse der neuen Art standen 5 in Nordborneo (Sabah) gesammelte Proben zu je 15 Bienen zur Verfügung. Eine weitere Probe aus Sumatra, die schon in der Sammlung Oberursel vorhanden war, konnte später ebenfalls als "Rote Biene" bestimmt werden. Die Vergleichsproben stammten ebenfalls aus dieser Sammlung.

Um die Stellung von A. koschevnikovi innerhalb der Gattung Apis zu bestimmen, wurde zunächst eine DiskriminanzAnalyse (beschränkt auf Flügelmerkmalemit sämtlichen bekannten Apis-Arten, also mit Einschlu $B$ der 12 Millionen Jahre alten A. armbrusteri aus dem Randecker Mar durchgeführt (Abb. 1). Die Exemplare der Roten Biene sind in einer geschlossenen Gruppe zu finden, eng angelehnt an $A$. cerana, aber weit entfernt von $A$. mellifera. Berechnet man den Vertrauensbereich der statistischen Abgrenzung bei $95 \%$, so ergibt sich eine starke Überlappung der konfidenzellipsen von $A$. koschevnikovi und $A$. cerana (Abb. 2).

Werden die drei höhlenbrütenden ApisArten für sich analysiert, so liegen die Porben von $A$. koschevnikovi zwischen den großen ( $A$. c. cerana) und den kleinen Formen ( $A$. $c$. indica) von $A$. cerana, weit entfernt von tropischen Rassen von $A$. mellifera (Abb. 3). Die Konfidenzellipsen von 95\% zeigen keine Überlappung (Abb. 4). Wird schließlich die Rote Biene gegenüber $A$. cerana mit all ihren Rassen allein getestet, so ergibt sich eine sehr klare Abgrenzung (Abb. 5).

A. koschevnikovi ist ganz wesentlich größer als die lokale Population von $A$. cerana indica; sie entspricht in ihrer Größe etwa den Rassen von $A$. mellifera aus derselben geographischen Breite (Tab. I). Da bei allen Bienenarten die Formen von Süden nach Norden zu größer werden, kann man annehmen, daß $A$. koschevnikovi dieselbe Größen-Variations breite wie $A$. mellifera hätte, falls es ihr gelungen wäre, in die gemäßigte Zone vorzudringen.

\section{REFERENCES}

Buttel-Reepen H. (1906) Apistica. Beiträge zur Systematik, Biologie, sowie zur geschichtlichen und geographischen Verbreitung der Honigbiene (Apis mellifica L.), ihrer Varietäten und der übrigen Apis-Arten. Veröff. Zool. Museum Berlin 117-201

Cornuet J.M. (1982) Représentation graphique de populations multinormales par des ellipses de confiance. Apidologie 13, 15-20

Koeniger N., Koeniger G., Tingek S., Mardan M. \& Rinderer T.E. (1988) Reproductive isolation by different time of drone flight between Apis cerana Fabricius 1793 and Apis vechti Maa 1953. Apidologie 19, 103-106

Maa T.C. (1953) An inquiry into the systematics of the tribus Apidini or honeybees (Hymenoptera). Treubia 21, 525-640

Rinderer T.E., Koeniger N., Tingek S., Mardan M. \& Koeniger G. (1989) A morphological comparison of the cavity dwelling honey bees of Borneo, Apis koschevnikovi (Buttel-Reepen, 1906) and Apis cerana (Fabricius 1793). Apidologie $20,405-411$

Ruttner F. (1985) Graded geographic variability in honeybees and environment. Pszcz. Zesz. Nauk 29, 81-92

Ruttner F. (1988) Biogeography and Taxonomy of Honeybees. Springer Verlag, Heidelberg

Ruttner F., Tassencourt L. \& Louveaux J. (1978) Biometrical-statistical analysis of the geographic variability of Apis mellifera. Apidologie 9, 363381

Ruttner F., Wilson R., Snelling G., Vorwohl G. \& Kauhausen D. (1986) The evolution of the honeybee wing venation. Apidologie 17, 349

Smith F. (1858) Catalogue of the Hymenopterous insects collected at Sarawak, Borneo, Mount Ophir, Malacca, and at Singapore, by A.R. Wallace. J. Proc. Linn. Soc. London Zool. $2,42-130$

Smith F. (1865) On the species and varieties of the honey-bee belonging to the genus Apis. Ann. Mag. nat. Hist. London 15, 372-380

Tingek S., Mardan M., Rinderer T.E., Koeniger N. \& Koeniger G. (1988) Rediscovery of Apis vechti (Maa: 1953): the Saban honey bee. Apidologie 19, 97-102 